\title{
Purchase of prescription and OTC medicines in Slovakia: factors influencing patients' expectations and satisfaction
}

\author{
Zuzana Haramiova*, Zuzana Kobliskova, Jurina Soltysova \\ Department of Organisation and Management of Pharmacy, Faculty of Pharmacy, Comenius University in Bratislava, \\ Slovak Republic
}

\begin{abstract}
Slovakia is a country where the purchase of OTC (over the counter) medicines outside the pharmacy is not allowed by the government. This study aimed at evaluating patients' satisfaction and acceptance of community pharmacists. Customer's behaviour and expectations influencing the purchase of prescription and OTC medicines were analyzed. A structured questionnaire having 15 multiple-choice questions was used to analyze the descriptive parameters. Data collection lasted from January to February 2014. The sample size consisted of 357 high-school educated individuals under 40 years of age. The survey showed that the prescription and OTC medicines were bought equally. The participants reported a $96.0 \%, 96.3 \%$ and $90.2 \%$ satisfaction rate with willingness and approach of the community pharmacist, pharmacy services and provision of drug information respectively. As for the OTC medicines, $89.5 \%$ people considered the pharmacist an expert: $88.2 \%$ purchased medicines with pharmacist's recommendation, $97.8 \%$ needed a professional counselling and $97.2 \%$ required a pharmacist's guidance. As for the prescription drugs, only $72.1 \%$ considered the pharmacist an expert: $96.3 \%$ suggested that physician's prescription was significant and $88.3 \%$ considered pharmacist's guidance in the process of selection of prescription medicines nonessential. A comprehensible and respectable conversation was highly expected in regards to both the OTC and prescription medicines.
\end{abstract}

Uniterms: Pharmaceutical Care/study/Slovakia. Community Pharmacy/Slovakia. Community Pharmacists/study/Slovakia. Patients/use of medicines. Patient satisfaction. Patient expectation. Medicines/prescription medicines.

\section{INTRODUCTION}

Two types of dispensing activities are inevitably performed in community pharmacies - dispensing of prescription medicines accompanied by professional consultation, and provision of over the counter (OTC) medicines along with advice on self-care (Pharmacy Board of Australia, 2015). Facing the challenges of self-care, pharmaceutical care has become even more important over the past decades. (WHO, 1998). For the pharmacists, their greater involvement in patients' self-care also means greater responsibility towards their customers. There is an increased need for accountability of pharmacists since appropriate self-medication is far from being a safe practice, particularly in the case of non-

\footnotetext{
*Correspondence: Z. Haramiova. Department of Organisation and Management of Pharmacy. Faculty of Pharmacy. Comenius University in Bratislava. Odbojarov 10, Bratislava 832 32. Slovak Republic. E-mail: haramiova@fpharm.uniba.sk
}

responsible self-medication (Ruiz, 2010). Community pharmacists are often the only health experts, able to help patients in making informed decisions about their self-care and prevent the risks associated with self-medication. Comprehensive and adequate dispensing processes of prescription and OTC medicines require greater focus on patients' health needs than on product marketing (Bennadi, 2013).

Studies report that people consider community pharmacists to be a credible and accessible source of information, particularly in the case of minor ailments and OTC medicines. They are widely accepted as qualified health care providers and drug experts (You et al., 2011; Catic, Jusufovic, Tabakovic, 2013). Although physicians are considered the most important source of information in regards to prescription medicines, good pharmaceutical counselling improves patients' knowledge, as well as the use of medicines (Horvat, Kos, 2015). Patients' satisfaction expresses how well the role of a pharmacist 
meets patients' expectations in real-life practice. Even though patients' satisfaction is not a precisely defined concept, it is recognised as an important quality indicator of the services delivery system (Al-Abri, Al-Balushi, 2014). The relationship between patient expectations and satisfaction is complex. Opinions vary on the extent to which patients' expectations and satisfaction influence their health outcomes. Some suggest that higher expectations predict greater satisfaction, others report that satisfaction may sometimes be deceptively high due to low expectations (Kassam, Collins, Berkowitz, 2012; Licina et al., 2012).

Slovakia, as a country in transition, provides mainly traditional pharmaceutical services, such as: dispensing of prescription and OTC medicines; prescription and OTC medicines counselling, self-care consultancy and preparation of medicines. A total of 4,419 pharmacists in 1,972 community pharmacies currently provide pharmaceutical care in Slovakia (Slovak Chamber of Pharmacists, 2016). Intensive development of pharmaceutical care in Slovakia, similar to other former post-socialistic countries, have brought many positive elements over recent years (Szalayova et al., 2014). Nevertheless, the traditional approach to pharmaceutical practice persists, and the progress of patient-oriented pharmaceutical care is slow. Dispensing of medicines, as the main part of pharmaceutical care is regulated by European legislation (Wiedenmayer $e t$ $a l ., 2006)$. Provision of medicines is restricted to bricks-andmortar pharmacies, whereas internet pharmacies can also provide OTC medicines. Prescription medicines account for approximately $89 \%$ of the overall turnover in Slovak pharmacies (Szalayova et al., 2014) while the share of OTC medicines is only around $10 \%$. The data describing the current position of community pharmacies as medicinal and business entities are limited (Malovecká et al., 2015). Most of the non-chain pharmacies face financial instability. Regardless of the lack of reliable information sources in this field, there are a few studies which map patients' satisfaction with pharmaceutical care and their expectations towards services provided by community pharmacies in Slovakia (Minarikova, 2015; Minarikova, Malovecká, Foltán, 2015).

The objective of this study was to identify the role of community pharmacists in prescription and OTC medicines counselling. Furthermore, it focuses on evaluating customer behaviour during the purchase of prescription and OTC medicines in relation to patient satisfaction and their expectations.

\section{METHODS}

We developed a structured survey instrument from an already published study (Villako, Volmer, Raal,
2012). All items were translated into the Slovak language using back translation. Subsequently, single items were slightly modified to assure clarity of understanding for lay population and to mirror the purpose of the survey better. The researchers performed a systematic face validity assessment of the final instrument in cooperation with five professionals in the field of pharmaceutical care in Slovakia. They agreed that the instrument showed a high level of face validity. The final questionnaire is included at the end of this article. It consists of fifteen multiple-choice items addressing the following aspects: (1) socio-demographic information (age, gender, education, monthly income) of surveyed participants; (2) purchase information of prescription medicines, OTC medicines and dietary supplements (vitamins, minerals and herbal products); (3) satisfaction with and trustworthiness towards community pharmacists in regards to pharmaceutical care provision; (4) expectations towards community pharmacists during the purchase of prescription and/or OTC medicines. For open questions, a four-point Likert scale was used. We performed pilot testing of the instrument on ten randomly chosen patients of a community pharmacy that were asked for additional feedback on wording, clarity, and format of the questionnaire and the accompanying instructions. Refinements were required within the accompanying instructions only. Results from pilot testing were not included in the final study analysis. Data collection took place from January to February 2014 using Google Drive Questionnaire system to reach the participants.

\section{RESULTS}

During the eight-week study period, 402 respondents participated in completing the questionnaire. From these, only 357 fully completed questionnaires and were included in the final study analysis. Respondents' characteristics are summarised in Table I. The majority of the participants were under 40 years of age $(79.8 \%)$, female $(61.7 \%)$ and high school educated $(69.7 \%)$. The results showed that during the last 12 months, participants had purchased both OTC (31.9\%) and prescription medicines (30.2\%) equally often. More specifically, prescription medicines for treatment of chronic diseases accounted only for $12.0 \%$ of the overall purchases, and Dietary supplements accounted for $26.1 \%$ of the overall purchases and the rest (11.8\%) of the purchases comprised of other goods (medical devices, baby food, cosmetics). Pharmacies located close to patients' places of residence (50.4\%), shopping centres $(27.2 \%)$ and health care facilities $(20.7 \%)$ were visited most frequently. Cold and cough 
medicines $(36.7 \%)$ together with analgesics for oral use $(26.3 \%)$ were the most frequently purchased OTC medicines. These were followed by topical analgesics and anti-inflammatory medicines $(11.2 \%)$, medicines for gastrointestinal disorders $(7.3 \%)$, antihistamines $(7.3 \%)$, tonics $(1.7 \%)$ and others $(9.5 \%)$.

Study participants showed high satisfaction (fully satisfied / rather satisfied) with the community pharmacists' willingness and approach $(96.1 \%)$ as well as with the community pharmacy services $(96.4 \%)$. Lower satisfaction was reported with the provision of drug information $(90.2 \%)$.

Most of the surveyed participants $(91.3 \%)$ considered the pharmacists to be experts on drugs and trusted them (certainly yes / probably yes). More specifically, the pharmacists were considered experts on prescription medicines and OTC medicines together with dietary supplements by $72.1 \%$ and $89.5 \%$ of the participants respectively.
While recommendation by a physician was the most important factor influencing the purchase of prescription medicines $(96.3 \%)$, recommendation by a pharmacist was the most important factor influencing the purchase of OTC medicines (88.2\%). Recommendation by family and friends was more significant for OTC than prescription medicines (53.2\% vs. $42.3 \%)$ and likewise was the price (58.6\% vs. $42.1 \%)$. The impact of drug advertisement on purchase decisions was reported to be small in both cases (5.2\% Rx; $12.6 \%$ OTC).

Participants reported high expectations towards pharmacists during the purchase of prescription as well as OTC medicines. Comprehensible conversation (99.2\% $\mathrm{Rx} ; 99.5 \%$ OTC) and respectable communication (99.0\% $\mathrm{Rx}$; 98.8\% OTC) count to the most frequent expectations of the participants. Pharmacist's guidance on the selection of appropriate medicines $(97.2 \%)$ and professional counselling $(97.8 \%)$ were significant expectations mostly in regards to OTC medicines.

TABLE I - Characteristics of the surveyed population $(n=357)$

\begin{tabular}{lcc}
\hline Characteristics & & $\mathbf{n}(\mathbf{\%})$ \\
\hline \multirow{2}{*}{ Gender } & Male & $137(38.3)$ \\
& Female & $220(61.7)$ \\
\hline \multirow{2}{*}{ Age (years) } & $\leq 25$ & $139(38.9)$ \\
& $26-40$ & $146(40.9)$ \\
& $41-55$ & $41(11.5)$ \\
& $\geq 56$ & $31(8.7)$ \\
\hline & Primary school & $10(2.8)$ \\
& Secondary school & $98(27.5)$ \\
& High school & $249(69.7)$ \\
\hline & $\leq 300$ & $119(33.3)$ \\
Monthly income (euro) & $301-800$ & $118(33.1)$ \\
& $\geq 801$ & $120(33.6)$ \\
\hline & Hospital & $6(1.7)$ \\
Localisation of the most visited type of & Health care facility & $74(20.7)$ \\
pharmacy & Place of residence & $180(50.4)$ \\
& Shopping centers & $97(27.2)$ \\
\hline & Rx medicines for acute disease & $65(18.2)$ \\
The most frequently purchased product & Rx medicines for chronic disease & $43(12.0)$ \\
from community pharmacies during the & OTC medicines & $114(31.9)$ \\
last 12 months & Dietary supplements & $93(26.1)$ \\
& Other & $42(11.8)$ \\
\hline & Analgesics & $94(26.3)$ \\
The most frequently purchased OTC & Medicines for gastrointestinal disorders & $131(36.7)$ \\
medicines from community pharmacies & Tonics & $26(7.3)$ \\
during the last 12 months & Analgesic and anti-inflammatory ointments & $6(1.7)$ \\
& Antihistamines & $40(11.2)$ \\
& Other & $26(7.3)$ \\
Rx - presciption & $34(9.5)$ \\
\hline
\end{tabular}

$\mathrm{Rx}$ - prescription medicines, OTC - over the counter medicines. 
TABLE II - Satisfaction with community pharmacists $(\% ; \mathrm{n}=357)$

\begin{tabular}{|c|c|c|}
\hline Level of satisfaction & $\begin{array}{c}\text { Fully satisfied } \\
\text { Rather satisfied } \\
\text { n (\%) }\end{array}$ & $\begin{array}{c}\text { Rather not satisfied } \\
\text { Not satisfied at all } \\
\text { n (\%) }\end{array}$ \\
\hline Satisfaction with information about drugs provided by pharmacists & $322(90.2)$ & $35(9.8)$ \\
\hline Satisfaction with willingness and approach of pharmacists & $343(96.1)$ & $14(3.9)$ \\
\hline
\end{tabular}

TABLE III - Recognition of the pharmacist as an expert on drugs $(\% ; n=357)$

\begin{tabular}{lcc}
\hline Level of recognition & $\begin{array}{c}\text { Certainly yes } \\
\text { Probably yes } \\
\text { n (\%) }\end{array}$ & $\begin{array}{c}\text { Probably no } \\
\text { Certainly no } \\
\text { n (\%) }\end{array}$ \\
\hline Do you consider the pharmacist to be an expert on prescription medicines? & $258(72.3)$ & $100(27.7)$ \\
Do you consider the pharmacist to be an expert on OTC medicines and dietary & $319(89.4)$ & $38(10.6)$ \\
supplements? & $326(91.3)$ \\
Do you trust the pharmacist to be an expert on medicines? & $31(8.7)$ \\
\hline
\end{tabular}

TABLE IV - Factors influencing the purchase of medicines $(\% ; \mathrm{n}=357)$

\begin{tabular}{lcccc}
\hline \multirow{2}{*}{ Factor } & \multicolumn{2}{c}{$\begin{array}{c}\text { Strongly agree / Agree } \\
\mathbf{n}(\mathbf{\%})\end{array}$} & \multicolumn{2}{c}{$\begin{array}{c}\text { Strongly disagree /Disagree } \\
\mathbf{n}(\%)\end{array}$} \\
\cline { 2 - 5 } & $\mathbf{R x}$ & $\mathbf{O T C}$ & $\mathbf{R x}$ & OTC \\
\hline Recommendation by physician & $344(96.3)$ & $296(83.0)$ & $13(3.7)$ & $61(17.0)$ \\
Recommendation by pharmacist & $314(88.0)$ & $315(88.2)$ & $43(12.0)$ & $42(11.8)$ \\
Recommendation by family and friends & $151(42.3)$ & $190(53.2)$ & $206(57.7)$ & $167(46.8)$ \\
Price & $150(42.0)$ & $209(58.5)$ & $207(58.0)$ & $148(41.5)$ \\
Advertisement & $19(5.3)$ & $45(12.6)$ & $338(94.7)$ & $312(87.4)$ \\
\hline
\end{tabular}

TABLE V - Participant's expectations towards pharmacists during purchase of medicines $(\% ; n=357)$

\begin{tabular}{|c|c|c|c|c|}
\hline \multirow{2}{*}{ Expectations } & \multicolumn{2}{|c|}{$\begin{array}{c}\text { Strongly agree / Agree } \\
\text { n (\%) }\end{array}$} & \multicolumn{2}{|c|}{$\begin{array}{c}\text { Strongly disagree / Disagree } \\
\text { n (\%) }\end{array}$} \\
\hline & $\mathbf{R x}$ & OTC & $\mathbf{R x}$ & OTC \\
\hline Professional counselling & $334(93.6)$ & $349(97.8)$ & $23(6.4)$ & $8(2.2)$ \\
\hline $\begin{array}{l}\text { Pharmacist's guidance on selection of appropriate } \\
\text { medicine }\end{array}$ & $315(88.2)$ & $347(97.2)$ & $42(11.8)$ & $10(2.8)$ \\
\hline Respectable communication & $353(98.9)$ & $352(98.6)$ & $4(1.1)$ & $5(1.4)$ \\
\hline Comprehensible conversation & $354(99.2)$ & $355(99.4)$ & $3(0.8)$ & $2(0.6)$ \\
\hline Fast and pleasant service & $341(95.5)$ & $340(95.2)$ & $16(4.5)$ & $17(4.8)$ \\
\hline Confidentiality in communication with pharmacists & $338(94.7)$ & $324(90.8)$ & $19(5.3)$ & $33(9.2)$ \\
\hline
\end{tabular}

\section{DISCUSSION}

Appropriate information provided to patients contributes to safe and effective treatment. Pharmacists and physicians play a key role in this process. They are the health care professionals authorised and obliged to provide specialised information as part of their dispensing and consulting activities. Their crucial importance lies not only 
in responsible guidance by choosing the right medicines, but also in the consecutive monitoring of the treatment, including self-medication. Currently, the main healthrelated activity of a pharmacist is to assure the quality of drug dispensing (Beney, Bero, Bond, 2000). Many factors related to pharmacists, patients and medicines affect the quality of drug dispensing process. A Brazilian study pointed out that pharmacists lack the satisfactory knowledge required for drug dispensing. The results showed that there is a need to restructure pharmaceutical education in respect to strengthening the role of the pharmacist in the pharmacotherapy (Reis et al., 2015).

Evaluation of patients' satisfaction with health care is considered to be a tool for improvement of its quality. It also indicates the fulfilment of patients' individual demands and needs. Previous publications confirmed high patient satisfaction with provided pharmaceutical care in Slovakia. In a regional survey, $82.0 \%$ of the respondents reported their satisfaction with provided pharmaceutical care (Minarikova, Malovecká, Foltán, 2015). The later national survey revealed a different evaluation of individual dimensions of pharmaceutical care: while $86.7 \%$ of the respondents provided a positive assessment of Interpersonal Relationship, only $65.4 \%$ of the respondents positively evaluated the Managing Therapy (Minarikova, 2015). This research consistently showed high patient satisfaction with the willingness and approach of community pharmacists $(96.0 \%)$ as well as with pharmacy services provided by community pharmacists $(96.3 \%)$. In this study lower satisfaction with information on medicines $(90.2 \%)$ was also reported. Pharmacy services offered in a community pharmacy include dispensing, product-related services and pharmaceutical care services, such as immunisations, smoking cessation assistance, health screening, medication therapy management, wellness screening, nutritional support, and disease management services (Doucette et al., 2006). Providing additional pharmacy services is consistent with the pharmacy professions movement to provide pharmaceutical care and to expand the roles of pharmacists in medication use beyond distributional activities. It is necessary to emphasise, that conditions for this type and extent of pharmacy services are not adequate in Slovakia and community pharmacists mainly offered dispensing and product related services.

High patient satisfaction was related to high patient expectations in our survey. Respondents expected comprehensible conversation, respectable communication including fast and pleasant service in case of prescription and OTC medicines. Professional counselling and guidance by the pharmacist on the selection of an appropriate medicine were the most important aspects in the case of OTC medicines. As Schommer concluded, patients' expectations and knowledge of counselling services provided by pharmacists are important for the provision of these services. The potential positive outcomes that result from counselling can remain unrealised if patients do not attend or comply with the counselling (Schommer, 1997). Confirming the results of an Estonian survey (Villako, Volmer, Raal, 2012), the purchase of medicines in Slovak community pharmacies is influenced mainly by recommendations from health care professionals. In the case of prescription medicines patients trust more physicians $(96.3 \%)$, while in case of OTC medicines, recommendations from pharmacists were more important than recommendations from physicians $(88.2 \%$ vs. $83.0 \%)$. This corresponds with the findings of our study where participants considered the pharmacist to be an expert on OTC medicines and dietary supplements $(89.5 \%)$ more than on prescription medicines (72.1\%). Furthermore, our study showed a low impact of drug advertisements and drug price on the purchase of medicines. The Slovak legislation does not allow advertisement of prescription medicines to the public, but advertisement of OTC medicines is intensive and frequent. Advertisement of products is a basic marketing tool for a successful purchase, although people do not recognise its impact on their decision-making process (Al-Haddad, Hamam, Al-Shakhshir, 2014).

Several studies investigated patient's perception of pharmacists (Catic, Jusufovic, Tabakovic, 2013) (Kelly et al., 2014). Minarikova puts forward that $73.6 \%$ of the respondents considered the pharmacist to be an expert on medicines, medical devices and other goods in the pharmacy. Furthermore, $65.1 \%$ of the respondents accepted the pharmacist as an advisor and expert on health issues, disease treatment, and disease prevention (Minarikova, Malovecká, Foltán, 2015). In the current study, $91.3 \%$ of the participants trusted the pharmacist as an expert on medicines. Paradoxically, pharmacists' self-evaluation is worse. They mostly viewed themselves primarily as "dispensers of medication," not patientcentred practitioners (Rosenthal et al., 2011).

The results of the current study need to be viewed and interpreted considering the following limitations. The questionnaire instrument used in our study was derived from a previous study conducted in Estonia without cross-cultural adaptation. Additionally, reliability and construct validity of the survey instrument were not evaluated; we assessed the face validity of the instrument only. Our study was also limited by its small sample size and over-representation of younger participants with higher education, which 
may not properly represent the overall Slovak population. Many variables, such as age, gender or education level can be significantly associated with the satisfaction level and patients' requirements on the pharmacist. Further, detailed analysis of the correlation between these factors and marketing data is necessary and highly recommended. The knowledge of these relationships could provide us with valuable information necessary for the provision of personalised high-quality pharmaceutical care.

\section{CONCLUSION}

This research, likewise the previous ones, points out that Slovaks are very satisfied with community pharmacists and have high expectations towards provided pharmaceutical care. Pharmacists are considered as trusted health care professionals and people accept them as counsellors mainly on OTC medicines and selfmedication. However, our study has also shown that pharmacists need to pay more attention to the provided information and should offer pharmaceutical services on a daily routine.

\section{REFERENCES}

AL-ABRI, R.; AL-BALUSHI, A. Patient satisfaction survey as a tool towards quality improvement. Oman Med. J., v.29, n.1, p.3-7, 2014.

AL-HADDAD, M.S.; HAMAM, F.; AL-SHAKHSHIR, S.M. General public knowledge, perceptions, and practice towards pharmaceutical drug advertisements in the Western region of KSA. Saudi Pharm. J., v.22, n.2, p.119-126, 2014.

BENEY, J.; BERO, L. A.; BOND, C. Expanding the roles of outpatient pharmacists: effects on health services utilisation, costs, and patient outcomes. Cochrane Database Syst. Rev., n.3, p.CD000336, 2000.

BENNADI, D. Self-medication: a current challenge. J. Basic Clin. Pharm., v.5, n.1, p.19-23, 2013.

CATIC, T.; JUSUFOVIC, F. I.; TABAKOVIC, V. Patients perception of community pharmacist in Bosnia and Herzegovina. Mater. SocioMed., v.25, n.3, p.206-209, 2013.

DOUCETTE, W.R.; KRELING, D.H.; SCHOMMER, J.C.; GAITHER, C.A.; MOTT, D.A.; PEDERSEN, C.A. Evaluation of community pharmacy service mix: evidence from the 2004 national pharmacist workforce study. $J$. Am. Pharm. Ass., v. 46, n.3, p.348-355, 2006.
HORVAT, N.; KOS, M. Contribution of Slovenian community pharmacist counselling to patients' knowledge about their prescription medicines: a cross-sectional study. Croatian Med.J., v.56, n.1, p.41-49, 2015.

KASSAM, R.; COLLINS, J. B.; BERKOWITZ, J. Patient satisfaction with pharmaceutical care delivery in community pharmacies. Patient Prefer. Adherence, v.6, p.337-348, 2012.

KELLY, D.V.; YOUNG, S.; PHILLIPS, L.; CLARK, D. Patient attitudes regarding the role of the pharmacist and interest in expanded pharmacist services. Can. Pharm. J.,v.147, n.4, p.239-247, 2014.

LICINA, P.; JOHNSTON, M.; EWING, L.; PEARCY, M. Patient expectations, outcomes and satisfaction: related, relevant or redundant? Evidence-Based Spine-Care J., v.3, n.4, p.13-19, 2012.

MALOVECKÁ, I.; PAPARGYRIS, K.; MINÁRIKOVÁ, D.; FOLTÁN V.; JANKOVSKÁ, A. Prosperity of community pharmacy evaluated by gross and net profit and suggested corrective measures. 10 years study. Acta Fac. Pharm. Univ. Comen., v.62, n.1, p. 20-24, 2015.

MINARIKOVA, D. Úroveň a faktory ovplyvňujúce pacientsku spokojnost's lekárenskou starostlivost'ou na Slovensku [Level and factors influencing the patients' satisfaction with the pharmaceutical care in Slovakia]. Česká Slovenská Farm., v.64, p.178-183, 2015. Available from: <http:// www.prolekare.cz/ceska-slovenska-farmacie-clanek/ uroven-a-faktory-ovplyvnujuce-pacientsku-spokojnost-slekarenskou-starostlivostou-na-slovensku-57256>. Access on: 20 Oct. 2015.

MINARIKOVA, D.; MALOVECKÁ, I.; FOLTÁN, V. Consumer satisfaction with pharmaceutical care in Slovak community pharmacies. Eur. Pharm. J., 62, n. 1, p. 25-30, 2015.

PHARMACY BOARD OF AUSTRALIA. Codes, guidelines and policies. Guidelines for dispensing of medicines. Australia, 2015. Available from: < http://www.pharmacyboard.gov.au/ Codes-Guidelines.aspx $>$. Access on: 10 Jan. 2016.

REIS, T.M.D.; GUIDONI, C.M.; GIROTTO, E.; RASCADO, R.R.; MASTROIANNI, P.D.C.; CRUCIOL, J.M.; PEREIRA, L.R.L. Knowledge and conduct of pharmacists for dispensing of drugs in community pharmacies: a crosssectional study. Braz. J. Pharm. Sci., v.51, p.733-744, 2015. 
ROSENTHAL, M.M.; BREAULT, R.R.; AUSTIN, Z.; TSUYUKI, R.T. Pharmacists' self-perception of their professional role: insights into community pharmacy culture. J. Am. Pharm. Ass., v.51, n.3, p.363-U76, 2011.

RUIZ, M.E. Risks of self-medication practices. Current Drug Safety, v.5, n.4, p.315-323, 2010.

SCHOMMER, J.C. Patients' expectations and knowledge of patient counselling services that are available from pharmacists. Am. J. Pharm. Educ., v.61, n.4, p.402-406, 1997.

SLOVAK CHAMBER OF PHARMACISTS. 2016. Available from: $<$ https://www.slek.sk/lekarne-gis-kraje>. Access on: Jan 12, 2016.

SZALAYOVA, A.; SKYBOVÁ, K.; KANDILAKI, D.; SZALAY, T. Analýza lekárenského trhu na slovensku a v českej republike. vývoj za posledných 10 rokov [Pharmaceutical Market in Slovakia and Czech Republic. Development over last the 10 years]. Bratislava: Health Policy Institute, 2014. Available from: <http://www.hpi.sk/ cdata/Publications/hpi_analyza_lekarenskeho_trhu.pdf $>$. Access on: 21 Dec. 2015.
VILLAKO, P.; VOLMER, D.; RAAL, A. Factors influencing purchase of and counselling about prescription and otc medicines at community pharmacies in Tallinn, Estonia. Acta Pol. Pharm., v.69, n.2, p.335-340, 2012.

WIEDENMAYER, K.; SUMMERS, R.S.; MACKIE, C.A.; GOUS, A.G.S.; EVERARD, M.; TROMP, D. Developing pharmacy practice: a focus on patient care. Geneva: World Health Organization, 2006.87p. Available from: $<$ http://www. fip.org/files/fip/publications/DevelopingPharmacyPractice/ DevelopingPharmacyPracticeEN.pdf $>$. Access on: 21 Oct. 2015.

WORLD HEALTH ORGANIZATION. WHO. The Role of the Pharmacist in Self-Care and Self-Medication. Hague: World Health Organization, 1998. Available from: <http://apps. who.int/medicinedocs/pdf/whozip32e/whozip32e.pdf $>$. Access on: Jan 2016.

YOU, J.H.; WONG, F.Y.; CHAN, F.W.; WONG, E.L.; YEOH, E.K. Public perception on the role of community pharmacists in self-medication and self-care in Hong Kong. BMC Clin. Pharmacol., v.11, p.19, 2011.

Received for publication on $03^{\text {rd }}$ March 2016 Accepted for publication on $08^{\text {th }}$ November 2016 


\section{ATTACHMENT: STUDY QUESTIONNAIRE}

Please reply to the following questionnaire. Participation in the survey is anonymous.

Please, select the most applicable response from the following items!

Age of the respondent (years):

\begin{tabular}{|c|c|c|c|}
\hline 1 & 2 & 3 & 4 \\
\hline 25 or less & $26-40$ & $41-55$ & 56 or more \\
\hline
\end{tabular}

Gender of the respondent:

\begin{tabular}{|c|c|}
\hline 1 & 2 \\
\hline Male & Female \\
\hline
\end{tabular}

Education of the respondent:

\begin{tabular}{|c|c|c|}
\hline 1 & 2 & 3 \\
\hline Primary school & Secondary school & High school \\
\hline
\end{tabular}

Your monthly income (euro):

\begin{tabular}{|c|c|c|}
\hline 1 & 2 & 3 \\
\hline 300 or less & $301-800$ & 801 or more \\
\hline
\end{tabular}

What type of pharmacy do you visit most frequently?

\begin{tabular}{|c|c|c|c|}
\hline 1 & 2 & 3 & 4 \\
\hline Hospital & Health care facility & Place of residence & Shopping centres \\
\hline
\end{tabular}

What pharmacy product did you purchase most frequently during the last 12 months?

from a community pharmacy? ${ }^{*}$ OTC medicines = medicines, which you can buy without prescription.

\begin{tabular}{|c|c|c|c|c|}
\hline 1 & 2 & 3 & 4 & 5 \\
\hline $\begin{array}{c}\text { Prescription medicines } \\
\text { for chronic diseases }\end{array}$ & $\begin{array}{c}\text { Prescription medicines } \\
\text { for acute diseases }\end{array}$ & OTC medicines & Dietary supplements & Other \\
\hline
\end{tabular}

What OTC medicines* did you purchase most frequently during the last 12 months?

from a community pharmacy? ${ }^{*}$ OTC medicines $=$ medicines, which you can buy without prescription.

\begin{tabular}{|c|c|c|c|c|c|c|}
\hline 1 & 2 & 3 & 4 & 5 & 6 & 7 \\
\hline Analgesics & $\begin{array}{c}\text { Cold, cough } \\
\text { drugs }\end{array}$ & $\begin{array}{c}\text { Medicines for } \\
\text { gastrointestinal } \\
\text { disorders }\end{array}$ & Tonics & $\begin{array}{c}\text { Analgesic and } \\
\text { anti-inflammatory } \\
\text { ointments }\end{array}$ & $\begin{array}{c}\text { Anti- } \\
\text { histamines }\end{array}$ & Other \\
\hline
\end{tabular}

How satisfied are you with community pharmacy services?

\begin{tabular}{|c|c|c|c|}
\hline 1 & 2 & 3 & 4 \\
\hline Fully satisfied & Rather satisfied & Rather not satisfied & Not satisfied at all \\
\hline
\end{tabular}

How satisfied are you with information provided by pharmacists about drugs?

\begin{tabular}{|c|c|c|c|}
\hline 1 & 2 & 3 & 4 \\
\hline Fully satisfied & Rather satisfied & Rather not satisfied & Not satisfied at all \\
\hline
\end{tabular}

How satisfied are you with the willingness and approach of the pharmacists?

\begin{tabular}{|c|c|c|c|}
\hline 1 & 2 & 3 & 4 \\
\hline Fully satisfied & Rather satisfied & Rather not satisfied & Not satisfied at all \\
\hline
\end{tabular}

Do you consider the pharmacist to be an expert on prescription medicines?

\begin{tabular}{|c|c|c|c|}
\hline 1 & 2 & 3 & 4 \\
\hline Certainly yes & Probably yes & Probably no & Certainly no \\
\hline
\end{tabular}


Do you consider the pharmacist to be an expert on over the counter medicines and dietary supplements?

\begin{tabular}{|c|c|c|c|}
\hline 1 & 2 & 3 & 4 \\
\hline Certainly yes & Probably yes & Probably no & Certainly no \\
\hline
\end{tabular}

Do you trust the pharmacist as an expert on medicines?

\begin{tabular}{|c|c|c|c|}
\hline 1 & 2 & 3 & 4 \\
\hline Certainly yes & Probably yes & Probably no & Certainly no \\
\hline
\end{tabular}

Which factors influence your purchase of prescription medicines?

For your answer, please use the scale 1-strongly agree, 2 - agree, 3-strongly disagree, 4 - disagree

\begin{tabular}{|l|l|l|l|l|}
\hline & 1 & 2 & 3 & 4 \\
\hline Recommendation by physician & & & & \\
\hline Recommendation by pharmacist & & & & \\
\hline Recommendation by family and friends & & & & \\
\hline Price & & & & \\
\hline Advertisement & & & & \\
\hline
\end{tabular}

Which factors influence your purchase of over the counter medicines?

For your answer, please use the scale 1-strongly agree, 2-agree, 3-strongly disagree, 4 - disagree

\begin{tabular}{|l|l|l|l|l|}
\hline & 1 & 2 & 3 & 4 \\
\hline Recommendation by physician & & & & \\
\hline Recommendation by pharmacist & & & & \\
\hline Recommendation by family and friends & & & & \\
\hline Price & & & & \\
\hline Advertisement & & & & \\
\hline
\end{tabular}

What do you expect from community pharmacists during the purchase of prescription medicines?

For your answer, please use the scale 1-strongly agree, 2-agree, 3-strongly disagree, 4 - disagree

\begin{tabular}{|l|l|l|l|l|}
\hline & 1 & 2 & 3 & 4 \\
\hline Professional counselling & & & & \\
\hline Pharmacist's guidance on selection of appropriate medicine & & & & \\
\hline Respectable communication & & & & \\
\hline Comprehensible conversation & & & & \\
\hline Fast and pleasant service & & & & \\
\hline Confidentiality in communication & & & & \\
\hline
\end{tabular}

What do you expect from community pharmacists during the purchase of OTC medicines?

For your agreement, please use the scale 1- strongly agree, 2 - agree, 3 -strongly disagree, 4 -disagree

\begin{tabular}{|l|l|l|l|l|}
\hline & 1 & 2 & 3 & 4 \\
\hline Professional counselling & & & & \\
\hline Pharmacist's guidance on selection of appropriate medicine & & & & \\
\hline Respectable communication & & & & \\
\hline Comprehensible conversation & & & & \\
\hline Fast and pleasant service & & & & \\
\hline Confidentiality in communication & & & & \\
\hline
\end{tabular}

